\title{
PROBABILITAS TERJADINYA TINDAK KEKERASAN TERHADAP WANITA DALAM RUMAH TANGGA: STUDI PADA MASYARAKAT BERBASIS PERTANIAN DI KABUPATEN BENGKULU UTARA
}

\author{
Agus Purwoko, Ketut Sukiyono, dan Basuki Sigit Priyono \\ Staff Pengajar Jurusan Sosek. Pertanian Fak. Pertanian Universitas Bengkulu
}

\begin{abstract}
ABSTRAK. Penelitian ini ditujukan untuk mengkaji faktor-faktor yang mempengaruhi probabilitas terjadinya tindak kekerasan dalam rumah tangga (KDRT) pada wanita/istri petani, dalam periode 3 dan 6 bulan terakhir. Metode deskriptif dan probit binary model digunakan untuk menganalisa data yang telah terkumpul melalui wawancara terhadap 200 wanita dari 4 desa di Kecamatan Padang Jaya Kabupaten Bengkulu Utara yang dipilih secara stratified random sampling berdasarkan basis ekonomi rumah tangga (RT) mereka, yakni RT perkebunan, RT perikanan air tawar, dan RT pertanian tanaman pangan. Jumlah responden untuk masing-masing desa ditentukan secara proporsional berdasarkan sub-populasinya dan pemilihannya juga dilakukan secara acak. Hasil penelitian menunjukkan bahwa probabilitas wanita/istri petani mengalami KDRT dalam 3 dan 6 bulan terakhir adalah $37 \%$ dan $48 \%$, dalam bentuk kekerasan fisik, psikologi, sosial-ekonomi, dan seksual. Penelitian ini juga menemukan bahwa perbedaan umur suami-istri, umur pernikahan, status ekonomi istri, dan perbedaan suku (etnik) suami-istri secara signifikan mempengaruhi probabilitas terjadinya KDRT pada wanita/istri petani, baik untuk periode 3 ataupun 6 bulan terakhir. Estimasi efek marjinal dari peubah bebasnya mengindikasikan bahwa persamaan etnik suami-istri dan status ekonomi istri memiliki kontribusi terbesar yang dapat mengurangi probabilitas wanita/istri petani mengalami tindak kekerasan dalam rumah tangganya.
\end{abstract}

Kata kunci: kekerasan dalam rumah tangga, probalititas, binary probit model

\section{THE INCIDENCE PROBABILITY OF VIOLENCE AGAINST WOMEN: CASE STUDY AT AGRICULTURAL SOCIETY IN DISTRICT OF NORTH BENGKULU}

\begin{abstract}
The research is aimed at explaining factors that influence probability of women experienced on domestic violence against women/farmer's wife know as kekerasan dalam rumah tangga (KDRT) within the last 3 months (KDRT 3) and the last 6 months (KDRT 6). An analytical descriptive method and the probit binary model are used to analyze data gathered from interview to 200 women came from four villages and selected by stratified random sampling based on economic base that are estate households, fishery households and food crop households. The research indicates that the probabiity of women experiencing domestic violence within the last 3 and 6 months are $37 \%$ and $48 \%$ respectively. Furthermore, the research also finds that age difference of couple, women's experienced marriage, women's economic status, and ethnic difference of couple
\end{abstract}


have statistically significant impacts on probability of women/farmer's wife experiencing domestic violence both in the last 3 and 6 months. Based on marginal effect of independent variables, ethnic similarity of couple and women's economic status have significant contributions for declining domestic violence against women/farmer's wife.

Key words: domestic violence, probability, binary probit model

\section{PENDAHULUAN}

Pasal 1 UU No. 23 tahun 2004 tentang Penghapusan Kekerasan Dalam Rumah Tangga disebutkan bahwa KDRT (domestic violence) adalah setiap perbuatan terhadap seseorang terutama perempuan, yang berakibat timbulnya kesengsaraan atau penderitaan secara fisik, seksual, psikologis dan/atau penelantaran rumah tangga termasuk ancaman untuk melakukan perbuatan, pemaksaan atau perampasan kemerdekaan secara melawan hukum dalam lingkup rumah tangga.

Terjadinya kasus kekerasan dalam rumah tangga (KDRT) tidak memandang budaya dan lokasi geografi. Banyak argumen yang menyatakan bahwa tindak KDRT yang terjadi di Indonesia utamanya disebabkan oleh faktor budaya. Suatu budaya yang tidak memandang wanita setara dengan pria atau nilai-nilai budaya patriarkis, menjadi penyebab sering terjadinya tindak KDRT terhadap wanita (Mitra, 2000; Ahmed-Ghosh, 2004; Susanto, 2008; Sriyanto, 2008; dan Pratomo, 2009). Dengan menggunakan data dan metode penelitian yang berbeda, banyak juga penelitian menyimpulkan bahwa faktor sosial ekonomi juga menjadi penyebab utama terjadinya KDRT (Straus et al,. 1980; Ferraro and Johnson, 1983; Susilowati, 2008; dan Komnas Perempuan, 2009).

Sebagian besar masyarakat di Kecamatan Padang Jaya Kabupaten Bengkulu Utara merupakan transmigran "bedhol desa" dari desa-desa di Kabupaten Wonogiri, Jawa Tengah yang wilayahnya tergusur oleh proyek pembangunan waduk "Gajah Mungkur" pada akhir 1970an. Sekarang, kecamatan Padang Jaya merupakan daerah pertanian andalan bagi kabupaten ini, baik subsektor perkebunan, pertanian tanaman pangan dan hortikultur maupun perikanan air tawar.

Sebagai istri petani, peran utama wanita berkaitan dengan aspek domestik yakni mengurus rumah tangga (suami dan anak-anaknya). Namun demikian, beberapa kajian (Susanto, 2008; Susilowati, 2008; dan Pratomo, 2009) menunjukkan bahwa para wanita juga harus berperan dalam aspek produktif (mempunyai pekerjaan sendiri atau membantu usahatani suaminya) untuk meningkatkan pendapatan rumah tangganya. Kenyataannya tidak semua wanita (istri petani) mampu melakukan peran ganda tersebut secara maksimal. Kondisi ini sering menyebabkan kekecewaan bagi suaminya dan kadang-kadang menjadi penyebab terjadinya KDRT.

Faktor-faktor budaya dan sosial-ekonomi sering menjadi penyebab terjadinya tindak KDRT terhadap wanita. Namun demikian, suatu kajian yang ditujukan untuk menganalisis kaitan antara atribut-atribut yang melekat pada wanita (untuk bahasan selanjutnya ditulis istri petani) dengan probabilitas terjadinya tindak kekerasan terhadap istri dalam rumah tangga petani sangat layak untuk dilakukan. 


\section{METODOLOGI}

Penggalian data/informasi dilakukan dengan metode survey (Bailey, 1987 and Dane, 1990) melalui observasi dan wawancara terhadap 200 istri petani. yang dipilih secara stratified random sampling berdasarkan pada basis ekonomi rumah tangga (RT) yakni RT perkebunan, RT periknan air tawar dan RT pertanian tanaman pangan. Dari 9 desa di Kecamatan Padang Jaya Kabupaten Bengkulu Utara dipilih 4 desa secara acak, yakni Margasakti, Tanjung Harapan, Padang Jaya, dan Sidomukti. Jumlah responden untuk masing-masing desa ditentukan secara proporsional berdasarkan sub-populasinya dan pemilihannya juga dilakukan secara acak.

Analisa deskriptif digunakan untuk menjelaskan secara komprehensif data yang diperoleh, sehingga akan diperoleh gambaran tentang sesuatu yang lazim atau unik dalam suatu masyarakat pertanian serta variasi-variasinya, khususnya yang berkaitan dengan KDRT terhadap isteri petani.

Binary probit model diformulasikan untuk menganalisa probabilitas terjadinya KDRT terhadap istri petani. Motivasi digunakannya model ini adalah adanya indeks variabel laten yang tidak terobservasi, yaitu kemungkinan resiko tindak KDRT dihadapi oleh istri petani, dimana nilai indeks resiko ini diasumsikan mempunyai bentuk linear dari variabel bebas yang terobservasi (lihat O'Donnell, 2000), sebagai berikut:

$$
I_{i}=x_{i} \beta
$$

(1)

dimana $I_{i}$ adalah indeks dari variabel laten yang tidak dapat diobservasi, $x_{i}$ adalah nonstokastik variabel bebas yang merepresentasikan atribut yang melekat pada istri petani, $\beta_{\mathrm{i}}$ adalah koefisien yang akan diestimasi, dan i adalah jumlah observasi, yakni 200 responden.

Karena $I_{i}$ tidak terobservasi, maka elemen $\beta_{i}$ dalam persamaan (1) tidak bisa diestimasi dengan teknik estimasi regresi linear yang biasa digunakan. Akan tetapi, dengan mengasumsikan bahwa responden akan mengalami tindak kekerasan selama enam bulan terakhir terakhir $\left(Y_{j}=1\right)$ jika indeks melebihi tingkat batas acak tertentu, $\mathrm{u}_{\mathrm{i}}$, maka indeks ini dapat diformulasikan sebagai berikut:

$$
Y_{i}\left\{\begin{array}{c}
1 \text { jika } \mathrm{I}_{i}>\vartheta_{i} \\
0 \text { jika yang lain }
\end{array}\right.
$$

Dengan demikian, probabilitas bahwa istri petani ke $i$ mengalami tindak kekerasan dalam rumah tangganya selama 3 dan 6 bulan terakhir dapat dirumuskan sebagai berikut: 


$$
\begin{aligned}
P_{i} & =P\left(I_{i}=1\right) \\
& =P\left(I_{i}>\vartheta_{i}\right) \\
& =P\left(\vartheta_{i}<I_{i}\right) \\
& =F\left(I_{i}\right) \\
& =F\left(x_{i} \beta\right)
\end{aligned}
$$

dimana $\mathrm{F}$ adalah fungsi distribusi komulatif (commulative distribution function $=c d f$ ) dari variabel acak $\mathrm{U}_{\mathrm{i}}$.

Secara teori ekonometrika, ada dua kemungkinan terkait dengan cdf. Model yang pertama adalah model logit dimana model ini disusun berdasarkan asumsi bahwa $\mathrm{F}(\mathrm{x})$ adalah cdf logistik (Brent, 1998). Sedangkan yang lain adalah probit model yang mengasumsikan $\mathrm{F}(\mathrm{x})$ merupakan $c d f$ dengan distribusi normal (lihat Rao, 1997). Pemilihan model ini lebih bersifat subjektif dan untuk tujuan penelitian ini, dimana model probit digunakan dengan alasan bahwa $\mathrm{u}_{\mathrm{i}}$ terdistribusi secara normal karena banyak variabel independen yang mempengaruhi probabilitas terjadinya tindak kekerasan dalam rumah tangga (Judge, et al., 1985) tentang pendekatan teori ekonometrika dalam pemilihan bentuk model ini.

Selanjutnya, parameter dalam model probit binary diestimasi dengan menggunakan metode maximum likelihood (Judge, et al.,1985; O'Donnell, 2000), karena ML mempunyai properti asimptotik yang baik, konsisten, efisien dan mempunyai distribusi normal. Fungsi likelihood dari model probit dapat dituliskan sebagai berikut:

$$
\begin{aligned}
L(\beta \mid \text { sample }) & =P\left(y_{1}\right) P\left(y_{2}\right) \cdots P\left(y_{n}\right) \\
& =\prod_{i=1}^{n=100} P_{i}^{y_{i}}\left(1-P_{i}\right)^{1-y_{1}} \\
& =\prod_{i=1}^{n=100} F\left(x_{i} \beta\right)^{y_{i}}\left(1-F\left(x_{i} \beta\right)\right)^{1-y_{1}}
\end{aligned}
$$

(3)

Metode $M L$ akan mengestimasi nilai $\beta$ yang akan memaksimumkan $L$. Program SHAZAM digunakan untuk estimasi model probit binary.

\section{HASIL DAN PEMBAHASAN}

Hasil analisis dan bahasan dibatasi untuk pengalaman istri petani mengalami KDRT pada tiga dan enam bulan terakhir, selanjutnya masing-masing disebut KDRT 3 dan KDRT 6.

\section{KDRT terhadap Istri Petani}

Dalam enam bulan terakhir (KDRT 6), istri petani yang mengalami tindak KDRT secara fisik (dipukul dan ditampar) jumlahnya relatif sedikit yakni 5 persen. Ketika KDRT ini terjadi, korban kekerasan berusaha menganggap kekerasan 
tersebut timbul karena kekhilafan sesaat dan berharap pasangannya berubah menjadi baik sehingga ketika suami meminta maaf dan bersikap mesra kepadanya, maka harapan tersebut terpenuhi untuk sementara. Namun demikian, Susilowati (2008) mengungkapkan bahwa kekerasan terjadi berulang-ulang sehingga menimbulkan rasa tidak aman bagi istri. Dengan demikian, siklus kekerasan terhadap istri tanpa disadari menjadi seperti lingkaran setan.

Tabel 1. Bentuk-bentuk KDRT dan jumlah istri petani yang mengalami KDRT

\begin{tabular}{|c|c|c|c|}
\hline \multirow{2}{*}{ No. } & \multirow{2}{*}{ Bentuk dan Jenis KDRT } & \multicolumn{2}{|c|}{ Jumlah Kasus KDRT $(n=200)$} \\
\hline & & KDRT 3 & KDRT 6 \\
\hline 1. & $\begin{array}{l}\text { Kekerasan Fisik } \\
\text { - Dipukul } \\
\text { - Ditampar }\end{array}$ & $\begin{array}{l}3(1,5) \\
9(4,5)\end{array}$ & $\begin{array}{c}5(2,5) \\
10(5)\end{array}$ \\
\hline 2. & $\begin{array}{l}\text { Kekerasan Psikologi } \\
\text { - Diancam } \\
\text { - Dibentak-bentak } \\
\text { - Dihina } \\
\text { - Dicaci-maki } \\
\end{array}$ & $\begin{array}{c}3(1,5) \\
46(23) \\
6(3) \\
12(6)\end{array}$ & $\begin{array}{c}6(3) \\
54(27) \\
8(4) \\
23(11,5)\end{array}$ \\
\hline 3. & $\begin{array}{l}\text { Kekerasan Sosial dan Ekonomi } \\
\text { - Dilarang kunjungi orang tua/saudara } \\
\text { - Dilarang bergaul dengan orang lain } \\
\text { - Tidak diberi nafkah } \\
\text { - Diberi nafkah sedikit } \\
\text { - Dilarang bekerja } \\
\end{array}$ & $\begin{array}{c}3(1,5) \\
2(1) \\
2(1) \\
5(2,5) \\
4(2) \\
\end{array}$ & $\begin{array}{c}3(1,5) \\
2(1) \\
4(2) \\
10(5) \\
13(6,5)\end{array}$ \\
\hline 4. & $\begin{array}{l}\text { Kekerasan Seksual } \\
\text { - Oral sex } \\
\text { - Variations of sex position }\end{array}$ & $\begin{array}{l}6(3) \\
8(4)\end{array}$ & $\begin{array}{l}6(3) \\
8(4)\end{array}$ \\
\hline
\end{tabular}

Sumber: Hasil survai (2009 diolah)

Keterangan:

- Jumlah kasus KDRT (3 dan 6 bulan terakhir) merupakan angka komulatif, di mana total istri petani yang mengalami KDRT $3=95$ orang dan KDRT 6 $=100$ orang.

- Angka-angka dalam kurung merupakan persentase istri petani yang mengalami KDRT.

- Beberapa istri petani mengalami lebih dari satu jenis KDRT, misalnya ketika istri petani mengalami kekerasan fisik (ditampar), disaat yang bersamaan yang bersangkutan dibentak-bentak dan dicaci-maki.

Persoalan merawat dan mendidik anak-anak dan perekonomian keluarga yang pas-pasan sering memicu terjadinya perbedaan pendapat (percekcokan atau pertengkaran) antara istri dengan suaminya. Apabila istri petani melakukan perlawanan terhadap suaminya yang lebih sering memaksakan kehendaknya, maka hal inilah yang menjadi penyebab terjadinya tindak kekerasan fisik terhadap istri. Akibat yang diderita istri petani, antara lain: pipinya merah, sebagian tubuhnya memar dan kepala terasa pusing/pening. Bahkan tindak kekerasan fisik 
juga mengakibatkan kesedihan dan ketakutan pihak istri apabila ditinggalkan pasangannya.

Persoalan KDRT secara fisik selama ini terjadi karena hadirnya mitos (baca: Susanto, 2008). Diantara mitos yang berkembang di masyarakat bahwa suami memukul dan menampar isteri hanya karena kekhilafan sesaat lantaran isterinya itu dianggap terlalu rewel, tidak setia, dan berani membangkang. Pada umumnya istri telah mengalami kekerasan dalam kurun waktu yang cukup lama, karena hampir-hampir tidak ditemukan isteri yang melapor kepada pihak yang berwajib. Mitos lainnya selama ini diyakini bahwa isteri yang disiksa adalah tipe isteri yang pembangkang.

Tabel 1 memperlihatkan bahwa kekerasan psikologis (diancam, dibentakbentak, dihina, dan/atau dicaci-maki) merupakan KDRT yang paling banyak dialami oleh istri petani di daerah penelitian. Rata-rata setiap istri menerima paling tidak satu kali tindakan kekerasan psikologi oleh suaminya pada KDRT 6, kecuali dibentak-bentak oleh suaminya yang frekuensinya sebanyak dua kali.

Persoalan merawat dan mendidik anak, perekonomian keluarga, kelalaian istri dalam mengurus rumah tangganya, kurang perhatian kepada suaminya, dan perilaku malas-malasan menjadi faktor penyebab terjadinya tindak kekerasan psikologi terhadap istri petani. Temuan menarik penelitian ini menunjukkan lebih dari dua pertiga ( 71,3 persen) istri petani mempunyai persepsi yang sama bahwa faktor-faktor tersebut sering menjadi penyebab terjadinya KDRT secara psikologis. Hal ini mengidikasikan bahwa faktor internal istri seringkali memancing terjadinya tindakan kekerasan dalam rumah tangganya. Bentuk kekerasan psikologi ini mengakibatkan luka di dalam jiwa istri petani, antara lain: kesedihan, kecemasan, ketakutan, rendah diri, dan sakit hati.

Masalah utama yang dihadapi istri sebagai korban KDRT saat ini adalah masih melekatnya nilai-nilai budaya yang memposisikan kaum wanita lebih rendah dari kaum pria atau nilai-nilai budaya patriarkis (Purba, 2006; Daniel, 2008; Sriyanto, 2008; Susanto; 2008; Susilowati, 2008; dan Pratomo, 2009). Umumnya istri petani cenderung diam, tidak menyadari akan hak-haknya sebagai seorang manusia, sehingga ketika yang bersangkutan mendapat perlakuan kekerasan psikologi, hal itu dianggap wajar. Kondisi ini disebabkan pepatah kehidupan berkeluarga yang merupakan salah satu norma sosial yang berlaku pada masyarakat di daerah penelitian "swarga nunut, neraka katut" artinya "apabila suami berperilaku positif maka istri ikut menumpang kebaikannya, namun jika suami berperilaku negatif maka istri harus ikut menanggungnya" masih menjadi pedoman bagi istri petani dalam membina keluarganya. Dengan kondisi seperti itu justru akan menambah dampak yang tidak baik bagi keluarga, sebab semakin diam seorang istri maka ada kemungkinan kejadian KDRT ini akan terus terulang.

Hasil penelitian (lihat Tabel 1) mengungkapkan bentuk kekerasan sosial, yang berupa larangan bagi istri untuk mengunjungi orang tuanya/saudaranya serta larangan untuk bergaul dengan orang lain, hanya diderita oleh sekitar $1,5 \%$ istri petani saja. Sementara itu, jumlah tindak kekerasan ekonomi (istri tidak diberi nafkah oleh suaminya, istri diberi nafkah tetapi jumlahnya tidak mencukupi kebutuhan keluarganya, dan istri dilarang bekerja oleh suaminya) sedikit lebih banyak dibanding kekerasan sosial. 
Pada tindakan kekerasan sosial, suami yang sering pergi dari rumah dan kurang bertanggung jawab pada keluarganya menjadi faktor penyebab terjadinya bentuk KDRT ini terhadap istri petani. Larangan petani kepada istrinya untuk tidak meninggalkan rumah, termasuk mengunjungi orang tua/saudaranya, dimaksudkan agar kondisi rumah tetap terawat dan menghindarkan aib keluarga jika istrinya menceriterakan situasi dan kondisi rumah tangganya kepada orang tua/saudaranya. Sementara itu, suami yang cemburuan dan melarang istrinya untuk tidak bergaul dengan orang lain. Larangan-larangan tersebut mengakibatkan istri petani menjadi bingung, stress, dan malu kepada orang tua/ saudaranya.

KDRT secara ekonomi terjadi apabila istri petani tidak diberi nafkah oleh suaminya untuk membiayai kehidupan keluarganya. Kondisi ini dimungkinkan ketika suami pergi merantau dan tidak mengirimkan penghasilannya kepada istrinya. Pemberian nafkah yang jumlahnya sedikit kepada istri disebabkan pendapatan suami relatif kecil atau suami lebih suka membelanjakan penghasilannya untuk keperluannya sendiri. Penggalian informasi di lapangan mengungkapkan, ketika suami memberikan nafkah yang jumlahnya sedikit, yang bersangkutan selalu mengatakan "cukup nggak cukup harus dicukupkan!" kepada istrinya. Kondisi tersebut mengakibatkan istri petani menjadi kesal, bingung, tertekan batinnya karena mengalami kesulitan dalam mengatur ekonomi rumah tangganya.

Banyak pekerjaan rumah yang harus diselesaikan seorang istri, misalnya: memasak, mencuci, menyeterika, membersihkan rumah, menjaga anak-anak, dan sebagainya menjadi alasan bagi petani untuk melarang istrinya bekerja. Kajian Pratomo (2009) memberikan gambaran bahwa di rumah, perempuan di wilayah perkebunan bertanggung jawab penuh untuk urusan rumah tangga dan merawat anak-anak sebagaimana norma umum yang berlaku di masyarakat. Laki-laki mendapat peran sebagai kepala keluarga, dan bertugas mencari nafkah. Kalau dilihat seperti itu sepertinya adil. Tetapi dalam prakteknya perempuan tidak cuma berperan sebagai istri, ibu rumah tangga dan pengasuh anak, tapi juga sebagai pencari nafkah. Sementara dalam Nova (20 Nov. 2008) dijelaskan pada dasarnya tidak ada masalah jika ada seorang istri bekerja apabila disepakati bersama dengan pasangannya. Yang menjadi masalah, sebelum menikah, calon suami sudah memberi syarat jika sudah menikah, istri harus berhenti bekerja dan mengatur keluarga saja. Ketika rumah tangga mengalami kesulitan ekonomi, suami tetap bersikukuh istri tidak boleh bekerja.

Hasil penelitian menunjukkan hal yang cukup menarik, di mana istri petani sebagai korban kekerasan seksual jumlahnya hanya sedikit, tetapi frekuensinya cukup tinggi pada KDRT 6 yakni oral sex dialami sebanyak $2 \%$ istri petani dengan rata-rata frekuensi sebanyak empat kali dan variations of sex position diderita sebanyak $4 \%$ istri dengan rata-rata frekuensi sebanyak dua kali. Kondisi ini disebabkan semakin banyak yang mengajarkan cara atau teknik berhubungan seks melalui VCD, majalah, dan ceritera sesama kaum lelaki. Akibatnya, para suami ingin menerapkannya tanpa kesepakatan terlebih dahulu atau pemaksaan hubungan seks kepada istrinya . Akibat lebih jauh, istri petani mengalami tekanan batinnya. Di satu sisi, istri merasa jijik, tetapi di sisi lain takut ditinggalkan suami jika menolaknya. 


\section{Estimasi Model dan Uji Statistik}

Model logit ini diestimasi dengan menggunakan pendekatan Maximum Likelihood Estimates (MLE). Hasil estimasi model didapatkan bahwa estimasi binomial untuk KDRT 3 sebesar 0,365 dan KDRT 6 sebesar 0,475. Artinya sebanyak $36,5 \%$ dan $47,5 \%$ istri petani mengalami KDRT, yang bentuknya: kekerasan fisik, psikologis, sosial-ekonomi, dan/atau seksual. Membandingkan dua angka pengamatan tersebut menunjukkan bahwa adanya kenaikan $11 \%$ terjadinya KDRT pada tiga bulan ke dua, sehingga dapat disimpulkan bahwa hampir $8 \%$ istri petani di daerah penelitian mengalami kekerasan dalam rumah tangga dalam setiap bulannya. Angka temuan ini sangat besar, meskipun dari survai yang dilakukan hampir tidak satupun istri yang mengalami kekerasan ini melaporkan kepada pihak yang berwajib (polisi). Salah satu alasannya, mayoritas mengatakan bahwa KDRT yang dialaminya merupakan masalah keluarga dan akan menimbulkan aib keluarga jika pihak-pihak lain mengetahuinya.

Hasil estimasi model yang disajikan pada Tabel 2 memperlihatkan bahwa nilai $\mathrm{R}^{2}$ pada masing-masing model KDRT 3 dan KDRT 6 adalah sebesar 12,896\% dan $14,34 \%$. Meskipun nilai goodness of fit kecil, tetapi Wooldridge (2000) mengatakan bahwa nilai goodness of fit tidak sepenting signifikansi secara statistik dan ekonomi dari peubah-peubah bebasnya, sehingga nilai tersebut dapat dan sering diabaikan. Uji likelihood ratio didapatkan bahwa nilai $L R_{\text {hitung }}$ pada model KDRT 3 dan KDRT 6 masing-masing sebesar 26,2099 dan 29,2882, yang lebih besar jika dibadingkan dengan nilai $\mathrm{LR}_{\text {tabel }}\left(\chi^{2}\right)$ pada tingkat kepercayaan $95 \%$ $(=16,666)$ maupun $99 \%(=21,666)$. Ini berarti model dalam penelitian ini sangat layak digunakan untuk menduga probabilitas terjadinya KDRT terhadap istri petani, baik pada 3 bulan ataupun 6 bulan terakhir.

.Hasil estimasi yang disajikan pada Tabel 2 didapatkan bahwa beda usia istrisuami (X1), umur pernikahan (X5), status ekonomi istri (X8), dan perbedaan suku suami-stri (X9) merupakan faktor penting yang mempengaruhi probabilitas terjadinya KDRT terhadap istri petani pada model KDRT 3. Sementara itu, hasil estimasi model KDRT 6 juga menunjukkan bahwa faktor beda usia istri-suami (X1), pendidikan istri (X2), umur pernikahan (X5), status ekonomi istri (X8), dan perbedaan suku suami-istri (X9) merupakan faktor penting yang mempengaruhi probabilitas terjadinya KDRT terhadap istri petani. Hasil uji statistik dan inteprestasi hasil masing-masing peubah bebas terhadap probabilitas terjadinya KDRT terhadap istri petani pada masyarakat berbasis pertanian ditampilkan pada halaman-halaman berikut. 
Tabel 2. Estimasi probabilitas istri petani yang mengalami KDRT pada tiga dan enam bulan terakhir

\begin{tabular}{|c|c|c|c|}
\hline \multirow{2}{*}{ No. } & \multirow{2}{*}{ Peubah Bebas } & \multicolumn{2}{|c|}{ KDRT } \\
\hline & & 3 Bulan & 6 Bulan \\
\hline 1. & Konstanta & $\begin{array}{c}2.0909 \\
(1.7435)\end{array}$ & $\begin{array}{c}3.7615 \\
(1.7185)\end{array}$ \\
\hline 2. & Beda Usia Suami-Istri (X1) & $\begin{array}{c}-0.1176 * * * \\
(0.068572)\end{array}$ & $\begin{array}{c}-0.16414 * * * \\
(0.068784)\end{array}$ \\
\hline 3. & Pendidikan Istri (X2) & $\begin{array}{c}-0.0826 \\
(0.073542)\end{array}$ & $\begin{array}{l}-0.1157 * * \\
(0.069635)\end{array}$ \\
\hline 4. & Jumlah Anak Balita (X3) & $\begin{array}{c}-0.0794 \\
(0.33040)\end{array}$ & $\begin{array}{c}0.0925 \\
(0.3189)\end{array}$ \\
\hline 5. & Status Pernikahan (X4) & $\begin{array}{c}0.3705 \\
(0.90346)\end{array}$ & $\begin{array}{l}-0.5901 \\
(0.9099)\end{array}$ \\
\hline 6. & Umur Pernikahan (X5) & $\begin{array}{l}-0.0342 * * \\
(0.023364)\end{array}$ & $\begin{array}{c}-0.04372 * * * \\
(0.02237)\end{array}$ \\
\hline 7. & Usia Istri Menikah Pertama (X6) & $\begin{array}{c}0.0097 \\
(0.06289)\end{array}$ & $\begin{array}{r}-0.0310 \\
(0.0607)\end{array}$ \\
\hline 8. & Pendapatan Rumah Tangga (X7) & $\begin{array}{c}0.0095 \\
(0013351)\end{array}$ & $\begin{array}{c}0.1138 \\
(0.01307)\end{array}$ \\
\hline 9. & Status Ekonomi Istri (X8) & $\begin{array}{c}-1.1744 * * * \\
(0.54432)\end{array}$ & $\begin{array}{l}-0.4594 * * * \\
(0.216686)\end{array}$ \\
\hline 10. & $\begin{array}{l}\text { Perbedaan Suku Suami-Istri (X9) } \\
\mathrm{R}^{2}\end{array}$ & $\begin{array}{c}-1.5614 * * * \\
(0.51410) \\
0.12896\end{array}$ & $\begin{aligned} &- 1.6179 * * * \\
&(0.5779) \\
& 0,14340\end{aligned}$ \\
\hline & LR hitung & $26.2099 * * *$ & $29.2882 * * *$ \\
\hline
\end{tabular}

Sumber: Hasil survai (2009, diolah)

Keterangan: Angka-angka dalam kurung menunjukkan standar error $* *, * * *$ signifikan pada taraf kepercayaan $90 \%(1,635)$ dan $95 \%$ $(1,972)$.

\section{Beda Usia Suami-Istri (X1)}

Riset di 16 negara sub Sahara Afrika (disitir Hanafi, 2009) memperoleh data bahwa selisih usia pengantin perempuan dengan pasangannya rata-rata terpaut minimal 10 tahun lebih tua. Model pernikahan dengan selisih usia terpaut jauh ini pada gilirannya sering menghadirkan "mimpi buruk" bagi pengantin perempuandimana mereka mengalami kekerasan (abuse and violence) dalam kehidupan rumah tangganya. 
Hasil uji statistik menunjukkan, hal yang berlawanan dengan kondisi tersebut di atas, di mana perbedaan usia suami-istri mempunyai pengaruh yang nyata dan negatif terhadap probabilitas terjadinya KDRT. Kesimpulan ini diperoleh dari uji t dimana peubah ini memiliki nilai $t_{\text {hitung }}(-1.7143)$ untuk KDRT 3 dan $(-2.3863)$ untuk KDRT 6 yang lebih kecil dari $t_{\text {tabel }}(-1.635)$. Hasil uji ini menunjukkan bahwa semakin jauh perbedaan usia antara suami dan istri akan menurunkan resiko istri mengalami kekerasan dalam rumah tangganya, atau sebaliknya semakin dekat (kecil) perbedaan usia suami-istri akan meningkatkan resiko istri mengalami kekerasan dalam rumah tangganya.

Temuan ini wajar, sesuai dengan kultur masyarakat Indonesia, karena perbedaan usia suami-istri yang jauh mengindikasikan adanya usia yang cukup matang dari pihak suami sehingga akan membawa kematangan dalam mengendalikan dirinya dan bertindak untuk mengelola rumah tangganya. Suami dapat menjadi sandaran istri sebagai pelindung dan "pengemong" bagi istrinya.

\section{Pendidikan Istri (X2)}

Tingginya tingkat pendidikan wanita akan mengurangi resiko mereka mengalami KDRT (Kingston-Riechers, 1998), sedangkan beberapa riset lain menemukan tidak adanya pengaruh nyata dari tingkat pendidikan wanita terhadap resiko mengalami KDRT. Artinya, kesimpulan bahwa pengaruh tingkat pendidikan wanita terhadap KDRT adalah inkonklusif (lihat Alen and Straus 1980; Ratner 1995; dan Klein et al., 1997).

Tidak konklusifnya kesimpulan itu juga didapatkan dari penelitian ini. Uji statistik pada model KDRT 3, peubah pendidikan istri petani bukan merupakan faktor penting yang mempengaruhi probabilitas terjadinya KDRT. Kesimpulan ini didapatkan dari uji $t$ dimana nilai $t_{\text {hitung }}(-1.123)$ lebih besar dari $t_{\text {tabel }}(-1.635)$. Temuan ini berbeda untuk model KDRT 6 , yang menemukan bahwa nilai $t_{\text {hitung }}$ (1.663) lebih kecil dari $t_{\text {tabel }}(-1.635)$ sehingga tingkat pendidikan istri petani yang diukur berdasarkan lama pendidikan berpengaruh nyata terhadap probabilitas terjadinya KDRT.

Meskipun hasil signifikansinya berbeda, tetapi kedua model memiliki tanda yang sama yakni negatif. Artinya naiknya tingkat pendidikan istri petani akan mengurangi resiko yang bersangkutan untuk mengalami kekerasan dalam rumah tangganya atau sebaliknya. Temuan ini cukup wajar, karena semakin tinggi pendidikan seorang istri akan mempunyai kecenderungan untuk dapat berpikir dan bertindak lebih bijak dalam pengelolaan rumah tangga bersama suaminya. Hal ini pada gilirannya akan berdampak pada rendahnya resiko istri petani untuk mengalami KDRT selama mengelola rumah tangganya.

\section{Jumlah Anak Balita (X3)}

Keberadaan atau ketiadaan anak sering menjadi faktor penting terhadap terjadinya kekerasan dalam rumah tangga. Koenig et al. (2006) menemukan bahwa ketiadaan anak dalam rumah tangga menyebabkan seringnya terjadi kekerasan fisik dalam rumah tangga. Selain keberadaan anak, bagi etnik tertentu jenis kelamin anak juga dapat menjadi penyebab terjadinya kekerasan domestik terhadap istri. Penelitian yang dilakukan Mitra (2006) menemukan adanya korelasi 
positif, di mana jika anaknya lelaki maka akan melindungi istri dari tindak kekerasan dari suaminya. Sementara itu, Sorenson et al. (1996) menemukan bahwa tidak ada bukti yang dapat menjelaskan jumlah dan umur anak menjadi penyebab terjadinya KDRT terhadap wanita.

Hasil penelitian ini menemukan tidak adanya pengaruh yang nyata antara jumlah anak balita dengan KDRT terhadap istri petani. Secara statistik peubah jumlah anak balita bukan menjadi faktor penting bagi peluang terjadinya kekerasan yang dialami istri petani di dalam rumah tangganya. Lebih jauh, jika dilihat dari tandanya maka tanda peubah ini pada KDRT 3 adalah negatif, sedangkan pada KDRT 6 adalah positif. Hasil ini menunjukkan bahwa pengaruh jumlah anak balita terhadap kekerasan domestik adalah inkonklusif.

\section{Status Pernikahan Istri (X4)}

Keutuhan dan kerukunan rumah tangga yang bahagia, aman tenteram dan damai merupakan dambaan setiap orang dalam mengarungi kehidupan berumah tangga. Namun tidak jarang gagal membina rumah tangganya lantaran harus bercerai. Hasil penelitian menjelaskan bahwa $6,5 \%$ istri petani yang menikah untuk kedua kalinya, 4\% diantaranya pernah mengalami kegagalan dalam berumah tangga (bercerai) pada pernikahan pertamanya. Melalui pengalaman pahitnya, mereka lebih berhati-hati sebelum memutuskan untuk menikah kedua kalinya, di mana dibutuhkan waktu sekitar 2 tahun dari perceraian sebelumnya ketika yang bersangkutan memutuskan untuk menikah kedua kalinya dengan harapan tidak terjadi perceraian kedua kalinya.

Hasil penelitian ini menemukan tidak adanya pengaruh yang nyata status pernikahan istri terhadap probabilitas terjadinya KDRT. Uji t dari peubah ini memperlihatkan nilai $t_{\text {hitung }}$ lebih kecil dari $t_{\text {tabel }}$ pada setiap level signifikansi, yang menginformasikan bahwa secara statistik peubah status pernikahan istri bukan menjadi faktor penting bagi peluang terjadinya KDRT. Jika dilihat dari tandanya, pada KDRT 3 positif dan pada KDRT 6 negatif, menunjukkan bahwa pengaruh status pernikahan istri terhadap kekerasan domestik adalah inkonklusif.

\section{Umur Pernikahan (X5)}

Hasil estimasi didapatkan bahwa ada pengaruh negatif dan nyata dari umur pernikahan dengan probabilitas istri petani mengalami tindak kekerasan domestik. Uji $t$ statistik terhadap koefisien umur pernikahan menunjukkan bahwa nilai $t_{\text {hitung }}$ peubah ini, yakni KDRT 3 (-1.647) dan KDRT 6 (- 1.9544) lebih kecil dari tabel. Meningkatnya umur pernikahan akan mengurangi secara signifikan peluang istri petani mengalami kekerasan domestik dari suaminya. Hasil ini sama dengan penelitian Koenig et al. (2006) di India yang menemukan bahwa ada hubungan yang signifikan antara umur pernikahan dengan terjadinya kekerasan dalam rumah tangga, di mana lamanya umur penikahan (15 tahun atau lebih) mempunyai hubungan negatif dengan resiko terjadinya kekerasan dalam rumah tangga, khususnya kekerasan seksual. 


\section{Usia Istri Menikah Pertama (X6)}

Pernikahan dini bagi seorang istri dapat membawa konsekuensi bagi dirinya dan juga rumah tangganya. Studi kasus di Bangladesh dan India, misalnya, wanita sering menikah pada usia dini dengan pria yang sudah berumur. Pada usia yang relatif muda biasanya wanita sedikit tabu, tidak tahu atau tidak mengerti sama sekali tentang seks atau inisiasi seksual yang berakibat pada trauma yang dialami oleh wanita muda ini (Bates et al., 2004). Dengan kondisi ini pada akhirnya sering bermuara pada terjadinya kekerasan yang dialami oleh wanita karena mereka pada posisi yang rentan dan tidak bisa bertahan.

Uji statistik menunjukkan peubah umur istri petani pada saat nikah pertama kalinya bukan menjadi faktor penentu baginya untuk mengalami KDRT. Kesimpulan ini didukung oleh hasil uji $t$ dimana nilai $t_{\text {hitung }}$ lebih kecil dari $t_{\text {statistik }}$ pada setiap level signifikansi. Ada dua alasan penting yang dapat menjelaskan temuan ini. Pertama, biasanya "pengantin muda" tinggal bersama orang tuanya untuk beberapa saat bahkan sampai satu tahun pertama. Dengan tinggal bersama orang tua, masih dimungkinkan bagi seorang istri untuk berkonsultasi dengan orang tuanya jika mengalami masalah terkait dengan pengelolaan rumah tangganya. Kedua, pernikahan yang mereka lakukan bukan merupakan pernikahan yang dipaksakan seperti halnya yang sering terjadi di India dan Bangladesh. Dengan demikian, pernikahan yang tidak didasarkan pada paksaan mempunyai kecenderungan lebih dapat menghargai satu sama lain dan biasanya sudah saling mengenali watak dan kepribadian masing-masing pasangannya.

\section{Pendapatan Rumah Tangga (X7)}

Penelitian ini menemukan bahwa ternyata pendapatan rumah tangga bukan merupakan faktor utama dalam mempengaruhi probabilitas istri petani mengalami KDRT, baik pada KDRT 3 ataupun KDRT 6. Kesimpulan ini didapatkan dari uji statistik dimana nilai t hitung peubah ini pada kedua model lebih kecil nilai $t$ tabel pada setiap tingkat signifikansi, juga didukung oleh tidak sesuainya tanda parameter yang diperoleh. Hal ini dapat dimengerti karena dengan latar belakang sebagai petani tentunya suami-istri sudah dapat menduga berapa besar pendapatan yang akan diperoleh dari usahanya. Hasil ini tentunya bertentangan dengan temuan-temuan di negara lain tentang korelasi antara pendapatan rumah tangga dengan KDRT. Hasil penelitian di Kanada oleh Pottie Bunge (2000) misalnya, menemukan bahwa tingkat kekerasan yang dialami oleh pasangan (istri) lebih tinggi pada rumah tangga dengan pendapatan di bawah $\$ 30 \quad 000$ dibandingkan dengan rumah tangga dengan \$60 000 atau lebih. Penelitian Berger (2002) juga menemukan hasil yang sama yakni tingkat KDRT pada rumah tangga dengan pendapatan rendah (kurang dari $\$ 20$ 000) sebesar $16 \%$ dibandingkan dengan $4 \%$ pada rumah tangga dengan pendpaatan $\$ 75.000$ atau lebih.

\section{Status Ekonomi Istri (X8)}

Faktor penting yang tampaknya berkaitan dengan kekerasan adalah ketidakmerataan pendapatan (Gartner, 1990), di mana istri yang tidak memiliki pendapatan sendiri akan menempatkan dirinya pada resiko untuk mengalami 
kekerasan oleh pasangannya. Penelitian Bowlus dan Seitz (2005) juga menemukan bahwa suami lebih memungkinkan untuk melakukan kekerasan pada pasangannya yang tidak bekerja.

Hasil uji t statistik menunjukkan bahwa status ekonomi istri petani, yang diukur dengan peubah dummi dimana peubah ini sama dengan 1 jika istri bekerja dan sama dengan 0 untuk istri yang tidak bekerja, merupakan faktor penting bagi probabilitas terjadinya KDRT terhadap istri petani. Uji ini diperoleh dari $t_{\text {hitung }}(-$ 2.1575) untuk KDRT 3 dan (-2.1211) untuk KDRT 6 yang lebih kecil dari $t_{\text {tabel }}$ pada taraf $95 \%$, yakni -1.972 . Dengan demikian, status istri petani yang bekerja lebih kecil kemungkinannya untuk mengalami KDRT dibandingkan dengan mereka yang tidak bekerja. Alasan yang dapat menjelaskan temuan ini adalah dengan bekerjanya istri petani berarti ada kesetaraan pada kontribusi pendapatan rumah tangga dan pada giliran selanjutnya akan ada kesetaraan peran dalam pengelolaan rumah tangga atau tidak ada dominasi ekonomi satu pihak ke pihak lain. Ketidakadaan dominasi ekonomi ini menutup atau paling tidak menurunkan gap sehingga peluang untuk terjadinya kekerasan dengan alasan ekonomi menjadi lebih kecil. Lebih jauh, peranan produktif istri secara ekonomi melindunginya dari kekerasan domestik. Kajian yang dilakukan oleh Mitra (2006) mengungkapkan bahwa para stri yang bekerja menyebabkan mereka memiliki autonomi yang melindungi mereka dari kekerasan domestik.

\section{Perbedaan Suku Suami-Istri (X9)}

Penelitian tentang pengaruh perbedaan etnik suami-istri terhadap terjadinya KDRT sering difokuskan pada etnik asli atau etnik pendatang. Misalnya, etnik Aborigin lebih sering mengalami kekerasan dalam rumah tangganya dibandingkan dengan non Aborigin (Kurrle, 1993). Contoh penelitian lain (Gill dan Thériault, 2005) yang menemukan bahwa masyarakat Aborigin 3 kali kemungkinan menjadi korban kekerasan dari pasangannya yakni $21 \%$ dibandingkan $7 \%$ dari etnik non Aborigin.

Hingga laporan ini dibuat, belum ditemukan adanya penelitian tentang kaitan perbedaan atau persamaan etnik dari suami-istri terhadap kemungkinan terjadinya kekerasan pada istri. Hasil penelitian ini menunjukkan bahwa perbedaan etnik antara suami dan istri memperbesar peluang istri petani mengalami kekerasan dari suaminya. Nilai $t_{\text {hitung }}$ peubah ini (-3.0372 dan -2.7995 masing-masing untuk KDRT 3 dan KDRT 6) lebih kecil dari $t_{\text {tabel }}(-1.635)$. Tanda negatif ke dua koefisien memberikan arah hubungan antara etnik suami dan istri, jika mereka berbeda etnik $(\mathrm{d}=0)$, maka istri mempunyai kecenderungan yang cukup tinggi untuk mengalami KDRT. Atau sebaliknya, jika etnik mereka sama $(d=1)$, maka probabilitas terjadinya KDRT terhadap istrinya relatif rendah.

Penjelasan dari temuan ini karena mayoritas masyarakat di daerah penelitian merupakan transmigran. Pengamatan lapangan menginformasikan bahwa pasangan suami-istri berasal dari suku yang sama (baca: Jawa) jumlahnya sebanyak 88,5 persen. Apabila suami dan istri berasal dari etnik yang sama, maka akan banyak persamaan (misalnya: bahasa, adat-istiadat, falsafah hidup, selera makan, selera berpakaian, dan sebagainya) di antara mereka berdua, sehingga komunikasi yang baik akan terjalin. Hal inilah yang dapat mengurangi konflik 
dalam rumah tangga, sehingga kemungkinan terjadinya tindak KDRT akan cenderung rendah (kecil).

Dengan melihat efek marjinal (marginal effect) peubah bebas, yang didapatkan dari hasil estimasi model, maka probabilitas resiko istri petani mengalami KDRT dapat dihitung. Tabel 3 berikut menyajikan hasil estimasi efek marjinal peubah bebas terhadap terjadinya KDRT terhadap istri petani.

Tabel 3. Efek marjinal peubah bebas terhadap terjadinya kekerasan dalam rumah tangga

\begin{tabular}{llcc}
\hline \multirow{2}{*}{ No } & \multicolumn{1}{c}{ Peubah Bebas } & \multicolumn{2}{c}{ KDRT } \\
\cline { 3 - 4 } & & 3 Bulan & 6 bulan \\
\hline 1 & Beda Usia Suami-Istri (X1) & -0.02665 & -0.04090 \\
2 & Pendidikan Istri (X2) & -0.01873 & -0.02634 \\
3 & Jumlah Anak Balita (X3) & 0.01802 & 0.02274 \\
4 & Status Pernikahan (X4) & -0.07929 & -0.13823 \\
5 & Umur Pernikahan (X5) & -0.00774 & -0.01089 \\
6 & Usia Istri Menikah Pertama (X6) & 0.02194 & -0.00773 \\
7 & Pendapatan Rumah Tangga (X7) & 0.02154 & 0.00283 \\
8 & Status Ekonomi Istri (X8) & -0.20834 & -0.10944 \\
9 & Perbedaan Suku Suami-Istri (X9) & -0.36933 & -0.35425 \\
\hline
\end{tabular}

Sumber: Hasil survai (2009, diolah)

Dari tabel 3 terlihat bahwa ada dua peubah yang memiliki kontribusi terbesar yang dapat mengurangi probabilitas istri petani mengalami tindak kekerasan dalam rumah tangganya, yaitu perbedaan suku suami-istri (X9) dan status ekonomi istri (X8). Kedua peubah itu secara statistik juga signifikan pada tingkat kepercayaan 95 persen. Dari hasil estimasi efek marjinal, perbedaan suku suami-istri memiliki nilai sebesar -0.36933 (KDRT 3) dan -0.3525 (KDRT 6). Perbedaan suku antara suami dan istri akan meningkatkan peluang istri sebesar 0.36933 dan 0.35425 untuk mengalami KDRT dengan asumsi faktor lain tetap. Dengan kata lain, jika suami-istri berasal dari suku yang sama akan cenderung menurunkan probabilitas istri petani untuk mengalami kekerasan di dalam rumah tangganya, baik untuk 3 bulan atau 6 bulan terakhir(cateris paribus).

Peubah status ekonomi istri juga mempunyai pengaruh menurunkan peluang istri petani mengalami kekerasan dalam rumah tangganya. Istri yang bekerja atau 
mempunyai pendapatan sendiri akan mempunyai probabilitas sebesar 0.20834 (KDRT 3) dan 0.10944 (KDRT 6) untuk tidak mengalami kekerasan dalam rumah tangganya dibandingkan dengan istri yang tidak bekerja, dengan asumsi faktor yang lain dianggap konstan (cateris paribus).

Selain kedua peubah tersebut, istri petani juga semakin kecil peluangnya untuk mengalami kekerasan domestik sejalan dengan bertambahnya umur pernikahan yang dijalani dengan suaminya. Secara rata-rata, jika bertambah 1 tahun pernikahan yang dijalani pasangan suami-istri, maka akan mengurangi peluang istri untuk mengalami kekerasan domestik sebesar 0,00774 dan 0,01089 masing-masing untuk KDRT 3 dan KDRT 6, dengan asumsi faktor-faktor yang lainnya konstan atau tidak berubah.

\section{KESIMPULAN DAN SARAN}

Dari hasil penelitian dan pembahasan dapat disimpulkan bahwa:

1. Sebanyak $36,5 \%$ istri petani mengalami KDRT pada tiga bulan yang terakhir (KDRT 3) dan 47,5\% istri petani mengalami KDRT pada enam bulan terakhir (KDRT 6) dengan bentuk: kekerasan fisik, kekerasan psikologi, kekerasan sosial-ekonomi, dan/atau kekerasan seksual.

2. Faktor penting yang mempengaruhi probabilitas terjadinya KDRT terhadap istri petani adalah: beda usia suami-istri, umur pernikahan, status ekonomi istri, dan perbedaan etnik suami-stri, baik untuk KDRT 3 ataupun KDRT 6.

3. Faktor persamaan etnik suami-stri dan status ekonomi istri memiliki kontribusi terbesar yang dapat mengurangi probabilitas istri petani mengalami tindak kekerasan dalam rumah tangganya.

berikut:

Beberapa implikasi kebijakan yang dapat disarankan adalah sebagai

1. Kajian ini didasarkan pada data dan informasi yang diperoleh dari istri petani dan suaminya melalui wawancara secara individual. Oleh karena itu, untuk penyusunan konsep kekerasan dalam rumah tangga (KDRT) yang spesifik lokasi dan berlaku umum sesuai dengan kondisi masyarakat setempat, diperlukan penggalian data/informasi lebih lengkap lagi melalui focus group discussion (FGD).

2. Masih begitu kuatnya tatanan nilai sosio kultural mengisyaratkan bahwa sebagai perangkap hukum, efektifitas Undang-Undang Nomor 23 Tahun 2004 tentang Penghapusan Kekerasan Dalam Rumah Tangga di lapangan, masih harus disosialisasikan secara komprehensif dan berkesinambungan.

3. Pemerintah dan para pendamping korban KDRT perlu membuat upaya khusus untuk meningkatkan kemandirian ekonomi bagi para korban (istri), selain memfasilitasi pemulihan psiko-sosial dan medisnya. 


\section{DAFTAR PUSTAKA}

Ahmed-Gosh, H. 2004. Chattels of society: Domestic violence in India. Violence Against Women, 10(1): $94-118$.

Allen, C., and M. Straus. 1980. Resources, Power, and Husband - Wife Violence. The social Causes Husband - Wife Violence. M. Strauss and G. Hotaling eds. Minieapolis University of Minnesota Press.

Bailey, K. D. 1987. Methods of Social Research. Third edition. The Free Press, New York.

Bates, L. M., S. R. Schuler, F. Islam, and Md Khairul Islam. 2004. Socioeconomics Factors and Processes Associated with Domestic Violence in Rural Bangladesh. Internasional Family Planning Perspectives. 30(4): 190 - 1999.

Berger, E. 2002. National Report on Abuse: Summary of Findings from the Berger Population Health Monitor. Ottawa: Health Canada.

Bowlus, A.J. \& S. Seitz 2005. Domestic Violence, Employment and Divorce. http://qed.econ.queensu.ca/pub/faculty/seitz/abuse11.pdf (Diakses pada tanggal 30 Juli 2009).

Brent, R .J. 1998. Estimating the effectiveness and benefit of alcohol treatment programmes for use in economic evaluation. Applied Economics. 30(2):217 226.

Dane, F. C. 1990. Research Methods. Brooks and Cole Publishing Company. California

Daniel. 2008. Kecenderungan Korban KDRT Tidak Melapor. http:/pdssurabaya.com/index.php?option=com_content\&task=view\&id=2272 \&Itemid=27_ (Diakses pada 19 Oktober2009)

Ferraro, K. and J. M. Johnson. 1983. How women experience battering: The process of victimization. Social Problems. 30:325-339.

Gartner, R. 1990. The Victims of Homicides: A Temporal and Cross-national Comparison. American Sociological Review, 55, 92-106.

Hanafi, Y. 2009. Islam dan Persoalan Perkawinan Anak di Bawah Umur (Child Marriage/Early Marriage): Tantangan Legislasi dan Harmonisasi Hukum Islam. http://www.pejuangislam.com/main.php?prm=berita\&var $=\quad$ detail\&id $=126$ (Diunduh pada 19 Oktober2009)

Judge, G. G., W. E. Griffiths, R.C. Hill, H. Lutkepohl and T.C. Lee. 1985. The Theory and Practice of Econometrics. $2^{\text {nd }}$ Ed. John Willey. New York. 
Klein, P., S. Gerberich, R. Gibson, G. Maldonado, C. Kruttschnitt, K. Larnzt and C. Renier. 1997. Risk Factor for Work Related Violent Victimization. Epidemiology. 8(4):408 - 413.

Komnas Perempuan (Komisi Nasional Anti Kekerasan Terhadap Perempuan). 2009. Catatan 2008: Kerentaan Perempuan terhadap Kekerasan Ekonomi dan Kekerasan Seksual. http://www.komnas perempuan.or.id/ 2009/03/17/catatan-tahunan-2008kerentaan-perempuan-terhadap-kekerasaneonomi-dan-kekerasan-seksual (Diakses pada 6 April 2009)

Koenig, M. A., R. Stephenson, S. Ahmed, S. J. Jejeebhoy, and J. Campbell. 2006. Individual and contextual determinants of domestic violence in North India. American Journal of Public Health. 96(1):1-7, January 2006.

Kurrle, S. 1993. Responding to elder abuse -- a follow-up study of interventions and outcomes. Australian Journal of Ageing. 12: 5-9.

Mitra, N. 2000. Domestic Violence as a Public Issue: A review of responses (Unit for women's studies). Mumbai, India: Tata Institute of Social Sciences.

O'Donnell, C. .J. 2000. Applied Nonlinear Modelling: Study Guide. Department of Econometrics, The University of New England. Armidale. Australia.

Pottie Bunge, V. 2000. Spousal Violence. In V. Pottie Bunge \& D. Locke (Eds.), Family Violence in Canada: A Statistical Profile 2000 (pp. 11-19). Ottawa: Statistics Canada.

Pratomo. 2009. Perempuan di Blok-blok Perkebunan. http://obortani. com.2009/ 03/27/perempuan-di-blok-blok-perkebunan/ (Diakses pada 15 April 2009)

Purba, T. O. H. 2006. Bagi Perempuan Medan, Belum Aman Walaupun Sudah Ada Rumah Aman Perempuan. Laporan penelitian, Rumah Aman Sinceritas dan Cahaya Perempuan Medan.

Rao, V. 1997. Wife beating in rural South India: A qualitative and econometric analysis. Social Science Methodology. 44(8):1169 - 1180.

Ratner, P. 1995. Indicators Exposure to Wife Abuse. Canadian Journal of Nursing Research. 27(1): $31-46$.

Sriyanto, Y. 2008. Ada Apa dengan Kekerasan Dalam Rumah Tangga? http://www.lodaya.web.id/?=2660 (Diunduh pada 4 September 2009)

Straus, M.A., R.J. Gelles and S.K. Steinmetz. 1980. Behind Closed Door: Violence in American Family. Sage. Beverly Hills California. 
Probabilitas Terjadinya Tindak Kekerasan Terhadap Wanita dalam Rumah Tangga: Studi

Pada Masyarakat Berbasis Pertanian di Kabupaten Bengkulu Utara

(Agus Purwoko, Ketut Sukiyono, Dan Basuki Sigit Priyono)

Susanto, A. 2008. Kekerasan Dalam Rumah Tangga, Tinjauan Berdasarkan No. 23 Tahun 2004 tentang Penghapusan Kekerasan Dalam Rumah Tangga. http://jateng.bkkbn.go.id/print.php?tid=2\&rid=18 (Diakses pada 4 September 2009)

Susilowati, P. 2008. Kekerasan Dalam Rumah Tangga Terhadap Istri. http://www.e-psikologi.com/epsi/individual-detail.asp?id=476 (Diakses pada 19 September 2009)

Wooldridge, J.M. 2000. Introductory Econometrics: A Modern Apprapach. South Western College Publishing. 